\title{
Zika virus in Brazil: an overview of public health policies
}

\author{
Zika vírus no Brasil: uma visão geral das políticas públicas de saúde
}

Zika virus en Brasil: una visión general de las políticas de salud pública

Heverton Valentim Colaço da Silva ${ }^{1 *}$, Almerinda Agrelli ${ }^{1}$, Ana Sofia Lima Estevão de Oliveira ${ }^{1}$, Ronald Rodrigues de Moura1, Sergio Crovella ${ }^{1,2}$, Lucas André Cavalcanti Brandão ${ }^{1,3}$.

\begin{abstract}
Objective: The purpose of this review was to discuss the effectiveness of public health policies in controlling Zika virus (ZIKV) in Brazil from 2015 to 2019 with an emphasis in the state of Pernambuco. Literature Review: Zika virus is an arbovirus primarily transmitted to humans by Aedes aegypti mosquitoes. Since 2015, the control of Aedes aegypti proliferation and diffusion has been a global subject of discussion due to its role in ZIKV transmission and the emergence of serious clinical symptoms resulting from this infection. In Brazil, the public policies established to control ZIKV outbreak were mostly based on vector control. Final Considerations: The coping model to manage the transmission vector of ZIKV is not showing to be effective. Furthermore, until the social factors that favor the development and maintenance of mosquito breeding sites are eradicated, Brazil will continue to be susceptible to new outbreaks of mosquito-driven arboviruses. Here, we discussed the effectiveness of public health policies for the control of ZIKV in Brazil from 2015 to 2019, with a primary focus on the state of Pernambuco (PE).
\end{abstract}

Key words: Zika virus, Public policy, Health policy, Arbovirus infection, Delivery of health care.

\section{RESUMO}

Objetivo: O objetivo desta revisão foi discutir a efetividade das políticas públicas de saúde no controle do vírus Zika (ZIKV) no Brasil no período de 2015 a 2019 com ênfase no estado de Pernambuco. Revisão Bibliográfica: $O$ vírus zika é um arbovírus transmitido principalmente aos seres humanos pelos mosquitos Aedes aegypti. Desde 2015, o controle da proliferação e disseminação do Aedes aegypti tem sido objeto de discussão global devido ao seu papel na transmissão do ZIKV e ao surgimento de sintomas clínicos graves decorrentes dessa infecção. No Brasil, as políticas públicas estabelecidas para controlar o surto de ZIKV foram baseadas principalmente no controle de vetores. Considerações Finais: O modelo de enfrentamento para gerenciar o vetor de transmissão do ZIKV não está demonstrando ser eficaz. Além disso, até que os fatores sociais que favorecem o desenvolvimento e a manutenção dos locais de criação de mosquitos sejam erradicados, o Brasil continuará suscetível a novos surtos de arbovírus. Aqui, discutimos a eficácia das políticas públicas de saúde para o controle do ZIKV no Brasil de 2015 a 2019, com foco principal no estado de Pernambuco (PE).

Palavras-chave: Zika virus, Política pública, Política de saúde, Infecções por arbovírus, Assistência à saúde.

${ }^{1}$ Laboratório de Imunopatologia Keizo Asami (LIKA) - Universidade Federal de Pernambuco (UFPE), Recife - PE. *E-mail: heverton.valentin@ufpe.com.br

2Departamento de Genética - Universidade Federal de Pernambuco (UFPE), Recife - PE.

${ }^{3}$ Departamento de Patologia - Universidade Federal de Pernambuco (UFPE), Recife - PE.

This study was financed by the National Council for the Improvement of Higher Education - Brazil (CAPES) - Finance Code 001. 


\section{RESUMEN}

Objetivo: El objetivo de esta revisión fue analizar la efectividad de las políticas de salud pública en el control del virus Zika (ZIKV) en Brasil en el período de 2015 a 2019, con énfasis en el estado de Pernambuco. Revisión Bibliográfica: El virus Zika es un arbovirus transmitido principalmente a los humanos por los mosquitos Aedes aegypti. Desde 2015, el control de la proliferación y propagación del Aedes aegypti ha sido objeto de debate mundial debido a su papel en la transmisión del ZIKV y la aparición de síntomas clínicos graves derivados de esta infección. En Brasil, las políticas públicas establecidas para controlar el brote de ZIKV se basaron principalmente en el control de vectores. Consideraciones Finales: El modelo de afrontamiento para administrar el vector de transmisión ZIKV no está demostrando ser efectivo. Además, hasta que se erradiquen los factores sociales que favorecen el desarrollo y mantenimiento de los sitios de reproducción de mosquitos, Brasil seguirá siendo susceptible a nuevos brotes de arbovirus. Aquí, discutimos la efectividad de las políticas de salud pública para el control del ZIKV en Brasil de 2015 a 2019, con un enfoque principal en el estado de Pernambuco (PE).

Palabras clave: Virus zika, Política pública, Política de salud, Infecciones por arbovirus, Prestación de atención de salud.

\section{INTRODUCTION}

Arboviruses, arthropod-borne viruses, have become a considerable public health problem globally over the last decades. Arboviruses transmitted by Aedes mosquitoes such as Zika virus (ZIKV), Dengue virus (DENV) and Chikungunya virus (CHIKV) rarely cause mortality but frequently lead to debilitating diseases (HUANG YJS, et al., 2019). ZIKV belongs to the Flaviviridae family, genus Flavivirus, and in most cases promotes mild febrile illness (KINDHAUSER MK, et al., 2016).

The ZIKV was first identified in Uganda, Africa, in 1947. The first outbreak occurred in 2007 in the Micronesia region, and since then, it has spread to the Pacific Islands in 2013, where a new epidemic was once again evident in French Polynesian. In Brazil, the presence of the virus was confirmed in 2015, in the state of Bahia and later in Rio Grande do Norte, Pernambuco, Rio de Janeiro, São Paulo and other states (NUNES J, PIMENTA D, 2016; DONALISIO MR, et al., 2017).

Arbovirus-related diseases represent a worldwide problem, especially in tropical areas, known to be favorable for the proliferation and dispersion of the Aedes aegypti mosquito, considered the main vector of the ZIKV (DONALISIO MR, et al., 2017). The definitive establishment of Aedes in the Americas was caused by climate change, deforestation, disorganized urbanization, expansion of cities, lack of water and basic sanitation and displacement of the population. These factors define the pathways of diseases, exerting a strong influence on viral mutation and on the genetic adaptations of viruses to hosts, vectors and new environments (NUNES J, PIMENTA D, 2016).

The increased number of tourist and commercial journeys claimed by globalization, together with the disorderly growth of cities and the ongoing environmental changes on the planet have had a significant impact on the transmission of numerous arboviruses in recent years (ARAÚJO et al., 2015; MARCONDES; XIMENES, 2016).

The relationship between the environment and the organization of physical spaces can directly imply the emergence of these diseases. Therefore, the need for territorial observation according to its specificities is of great importance, aiming at the identification of diseases and how they occur, what services the population needs, which places offer potential risk to health and the environment, identifying the vulnerable populations and the situation in which they find themselves. In this context, basic sanitation services can be a determining factor related to both the incidence and prevalence of arboviruses (QUEIROZ JTM, et al., 2020).

The recurrent epidemics of arboviruses emphasize the need for greater control and prevention of endemic diseases, as well as better health education. Arboviruses represent a constant threat to public health and have 
demanded great efforts to control them around the world, no different here in Brazil (NUNES J, PIMENTA D, 2016; QUEIROZ JTM, et al., 2020).

Where the great impact caused by arboviruses, such as ZIKV, is due to the fact of its high transmission capacity, precisaly to its ease of adaptation to new environments and hosts. These characteristics are conducive to the appearance of outbreaks and greater risks to the health of those affected (DONALISIO MR, et al., 2017).

During 2015 in Brazil, an outbreak caused by ZIKV, could be for the first time correlated with the emergence of neurological disorders in neonates (SCHULER-FACCINI L, et al., 2015). This condition was later named Congenital Zika Syndrome (CZS). In addition, the development of Guillain-Barré syndrome was observed in adults and other neurological disorders in fetuses, such as the presence of calcifications in the periventricular parenchyma and regions of the thalamus, ventriculomegaly, lysencephaly and pachygyria, suggesting the presence of abnormal cell migration in the first gestational trimester (CHANG et al., 2016; SOLOMON T, et al., 2016; ZANLUCA C, et al., 2015).

Brazil is divided into 5 geographical regions: South, Southeast, Midwest, North and Northeast. According to Brazil's Atlas of Human Development Index (http://www.atlasbrasil.org.br), among the 27 Brazilian states, Pernambuco (PE), a state in the northeast region, occupies the $19^{\text {th }}$ position $(0.673)$ in the rank of the Human Development Index (HDI). HDI is a type of measurement composed of three-dimensional indicators of human development: longevity, education and income. This index ranges from 0 to 1 . The closer to 1 , the greater the development. Furthermore, PE has a large concentration of low-income individuals and was one of the main regions affected by the 2015 ZIKV outbreak (FARIA DOS SANTOS V, VIEIRA CV, 2016). It is important to note that PE was the first state to identify an increase in microcephaly cases, which led to further virus implication in this clinical outcome.

Between August 2015 and September 2016 PE registered 364 confirmed cases of microcephaly, whereas previously the annual average was 9 confirmed cases. Also, during this time period 6 cases of other neurological alterations related to ZIKV were confirmed. Of these, four were described as Guillain-Barré syndrome and 2 as acute disseminated encephalomyelitis. ZIKV involvement in these cases were confirmed by serum and cerebrospinal fluid analysis (NETA TJC, et al., 2016).

After notification regarding the increased number of head circumference alterations in newborns, the Brazilian government decided to declare a Public Health Emergency of National Importance (Emergência em Saúde Pública de Importância Nacional, ESPIN), emphasizing the need for prevention, control and containment of risks related to public health (TEIXEIRA MG, et al., 2016).

According to Decree № 7.616, ESPIN is declared in situations of epidemiological threat (which could be any of these upcoming cases: have risk of national dissemination, be produced by unexpected infectious agents, reintroduce eradicated diseases, present high severity or extrapolate the responsiveness of the state board of the Unified Health System-SUS), disaster or lack of assistance to the population (BRASIL, 2011).

As a reflection of the importance that the theme has achieved, precisely because of the associated diseases, it has become one of the main international health guidelines, including the status given by the World Health Organization (WHO) of Public Health Emergency of International Importance (ESPII), which was in force between February and November 2016.

The Zika epidemic and the ESPII declaration demanded intersectoral responses, not only in the technicalbiological sphere, but also in strengthening health and social protection systems, improving infrastructure and creating a legal framework that support the most vulnerable, who constituted and still constitute the risk group, mainly pregnant women (BRASIL, 2016b; NUNES J, PIMENTA D, 2016; DONALISIO MR, et al., 2017; JESUS UH, et al., 2018; QUEIROZ JTM, et al., 2020).

Since a substantial decrease in the number of Zika fever cases was observed in a May 2017 risk assessment, the Brazilian Government decided to end ESPIN, only eighteen months after its implementation. It is believed that this substantial decrease is due, in large part, to the public health measures adopted by the 
government, which accomplished this via direct investments in research and basic sanitation as well as through public awareness campaigns highlighting the importance of preventing the spread of Aedes aegypti. This underscores the decisive role of state-driven health policies in implementing such measures (BRASIL, 2017a).

In Brazil, public health issues have always been a regular part in the government agenda. However after the outbreaks of DENV, CHKV and more recently ZIKV, all of which transmitted through the same vector, arboviruses began to influence the government's decision-making agenda indefinitely (MIRANDA VMC, 2017).

Therefore, we aim to briefly discuss the effectiveness of these public health policies and actions during the years of 2015 to 2019 , with a primary focus on the state of PE.

\section{LITERATURE REVIEW}

\section{Local and national impact of arboviruses}

Since the notifications began in November 2015 through December 2018 the Brazilian Ministry of Health has been notified of 17,041 suspected cases of growth and developmental changes possibly related to ZIKV infection. Most of the notified cases were concentrated in the Northeast region of the country (58.5\%), followed by the Southeast $(25.1 \%)$ and the Midwest $(7.5 \%)$.

In the Northeast region 2,122 cases were confirmed. More specifically, PE was the state with the highest number of notifications $(2,797)$. It was also the state with the second largest number of confirmed cases $(471)$ and confirmed deaths (42), behind only the state of Bahia (485 and 52, respectively) (BRASIL, 2019a). Chart 1 Shows the number of reported cases of newborns and children with growth and developmental changes possibly related to ZIKV infection in Brazil and PE.

Chart 1 - Reported cases of newborns and children with developmental changes possibly related to ZIKV infection in Brazil and PE.

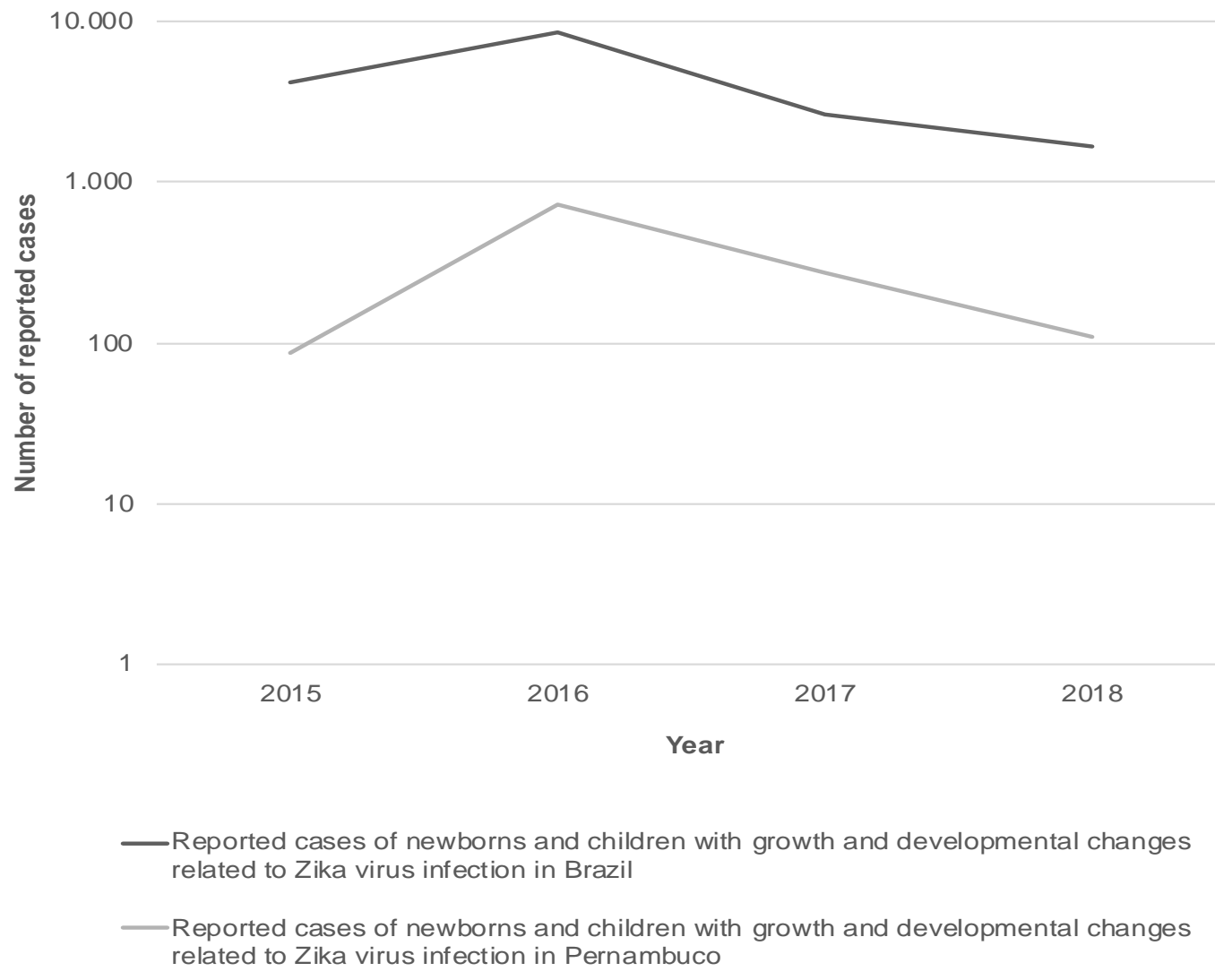

Source: Silva HVC, et al., 2020. 
We used a Pairwise comparisons for proportions to test if the proportions of the PE reports compared to the Brazilian reports are statistically changing over the years. As result, we observed a significant increasing (Bonferroni's corrected p-value $<0.05$ ) in the number of cases from 2015 to 2017 (year by year PE/BR ratio = $0.0209,0.0833$ and 0.1021 , respectively), and then a decrease in 2018 (PE/BR ratio $=0.0658$ ) (NEWCOMBE RG, 1998; WILSON EB, 1927).

In addition to these serious clinical consequences, ZIKV has a major impact on public health also due to its milder symptoms, condition named Zika fever. Through August 2019 Brazil had registered 1,439,471 probable cases of DENV, 110,627 probable cases of CHKV and 9,813 probable cases of Zika fever (BRASIL, 2019b).

Based on the need to have a survey capable of generating timely information to increase the effectiveness of combating the Aedes aegypti vector, the Ministry of Health has launched a rapid index survey program for Aedes aegypti (Levantamento Rápido de Índices para Aedes aegypti, LIRAa) for entomological surveillance of this vector in Brazil (BRASIL, 2013). Despite public and social policies adopted by the government in an attempt to curb the spread of Aedes aegypti, the first entomological survey of 2019 showed alarming numbers: 5,214 Brazilian municipalities were analyzed, of which 1,804 (36.4\%) were considered adequate, 2,160 (43.6\%) were considered at risk and $994(20 \%)$ were considered on alert for arboviral infections due to the high incidence of the vector (BRASIL, 2019d). In PE, one hundred and twenty eight (69.6\%) cities were at arboviruses alert and risk of high transmission (PERNAMBUCO, 2019a).

In Brazil, from 12/30/2018 to 8/24/2019, 1,439,471 probable cases of DENV, 110,627 probable cases of CHKV and 9,813 probable cases of ZIKV were registered. In the same period of 2018, 205,791 probable cases of DENV, 76,742 probable cases of CHKV and 6,669 probable cases of ZIKV were recorded, which represents an increase of $599.5 \%, 44 \%$ and $47.1 \%$, respectively, in the number of cases in the national territory. This alarming increase indicates that public policies against the vector must be reinforced nationwide. The number of probable cases of ZIKV, DENV and CHKV in Brazil and PE is shown in Figure 1 (BRASIL, 2015b; BRASIL, 2016c; BRASIL, 2017b; BRASIL, 2018a; BRASIL, 2019c). The nomenclature "probable cases" refers to all reported cases except those that have already been discarded.

Applying the same statistical approach used to analyze reported cases of newborns and children with growth and developmental changes related to ZIKV, we noted significant changes in the year by year PE/BR ratio of probable cases of ZIKV. From 2016 to 2018, there was an increase in the ratio from 0.0018 to 0.0022 and then 0.0130 along these years. Comparing the data from august 2019, the year by year PE/BR ratio of probable cases are still increasing to 0.0445 . 
Figure 1 - Number of probable cases of ZIKV, DENV and CHKV.

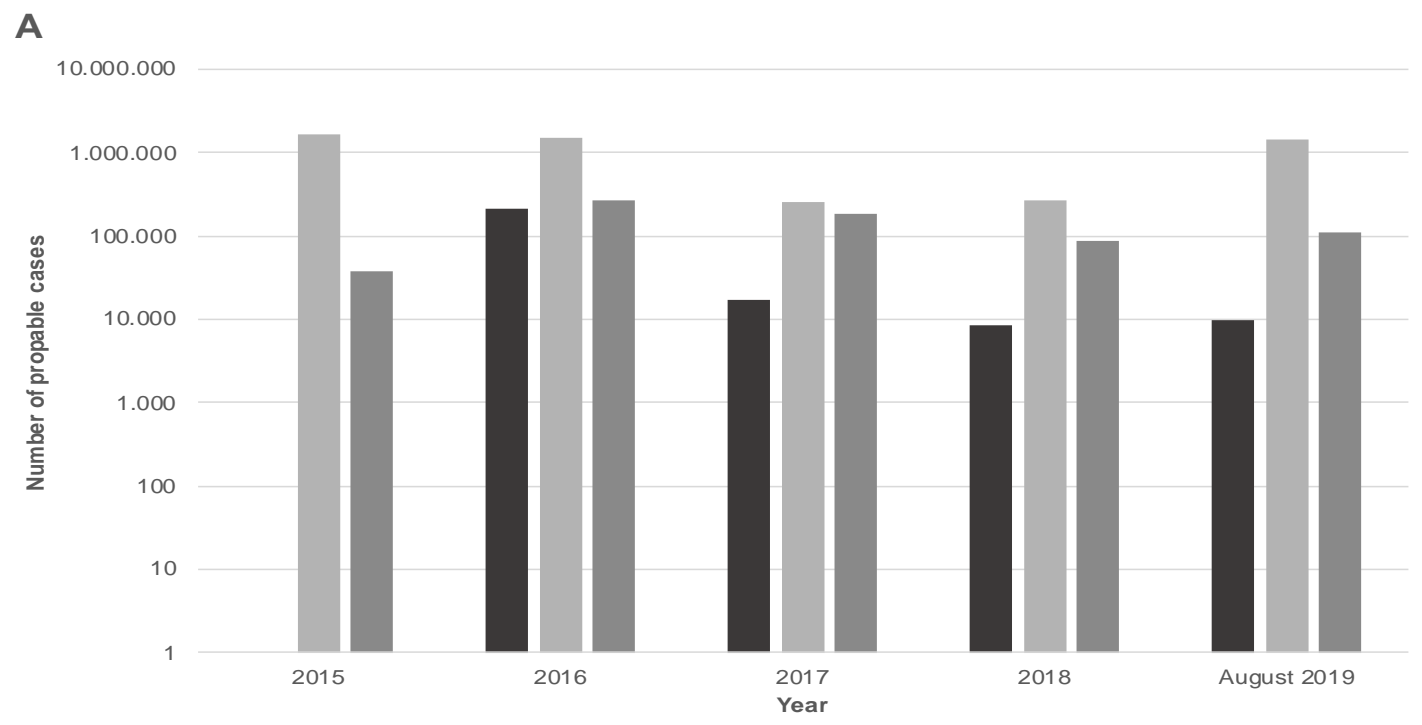

B

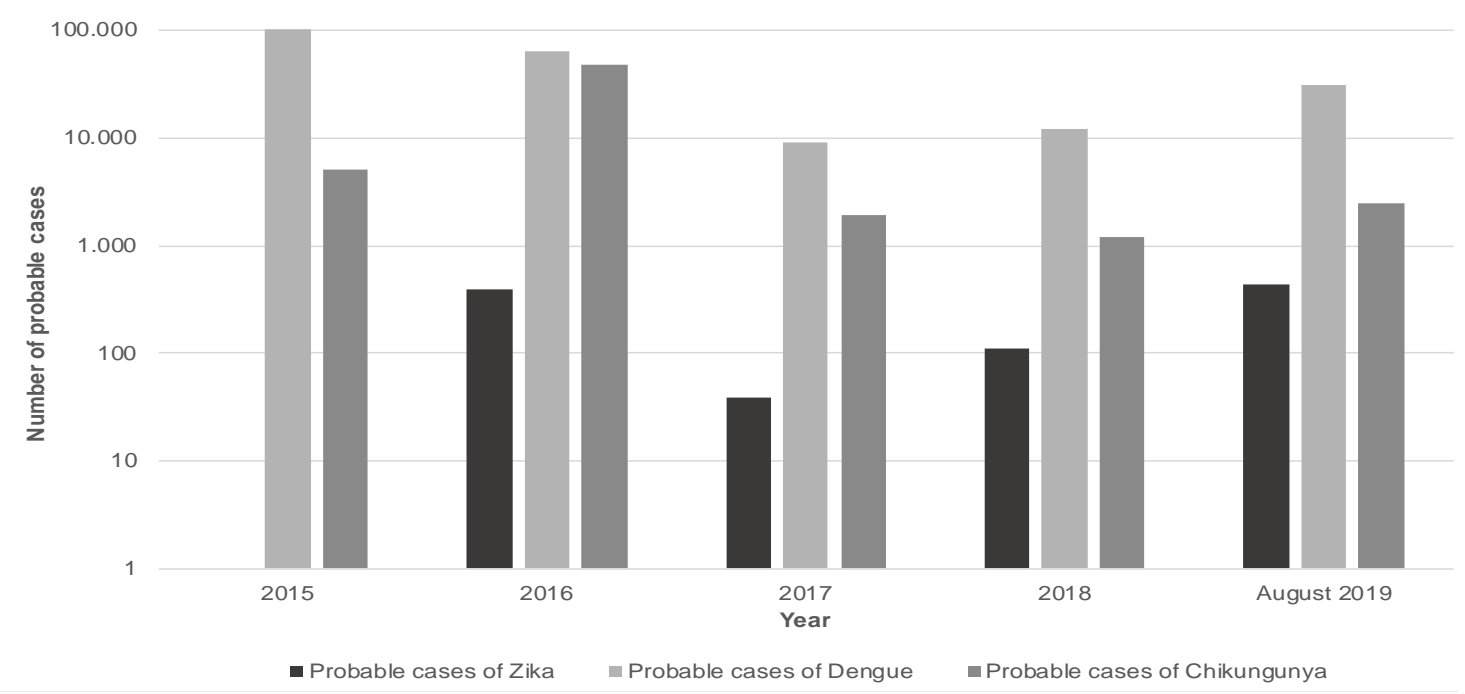

Source: SILVA HVC, et al., 2020.

Probable cases in Brazil (A) and PE (B) between 2015 (Zika outbreak start date in Brazil) and 2019. Of note the data for Zika for 2015 cannot be used as a comparison as it refers only to the last months of the year.

\section{Health policies and actions in the control of ZIKV}

The transmission of ZIKV in Brazil raises many concerns: the social and ecological context in the Americas, particularly in Brazil, favors the propagation of arboviruses; the climatic and environmental conditions are adequate for the activity and reproduction of the vector; crowded cities with intense flow of travelers makes Brazil not only vulnerable to large outbreaks but also a point of dispersal of cases to the rest of the world. Several studies have been proposed or are underway to answer basic questions about this emerging disease, but still little is known (SOUZA WV, et al., 2018).

As of December 2015, 2,975 suspected cases of microcephaly related to ZIKV infection had been reported in 658 municipalities in 20 states, 1,153 cases in just the state of PE (BRASIL, 2016b). In this context, the executive branch established the National Plan to Combat Microcephaly, which had objectives to provide 
assistance to the population, vector control and technological development, education and research (BRASIL, 2015b).

Because of the lack of knowledge about ZIKV, the serious clinical consequences of infection, and the favorable climate conditions for the vector there was a need to implement other urgent and effective actions. Thus, in 2015, the Decree № 8.612 of December 21 was established, and it was responsible for the creation of the National Coordination and Control Room.

This Decree had the intention of managing and monitoring actions to intensify the fight against the mosquito vector through defining guidelines; coordinating actions aimed at the availability of human resources, inputs and equipment; monitoring the measures implemented and the installation of District Halls in other spheres of government (BRASIL, 2015a).

A significant problem for the effectiveness in the control of the transmission of ZIKV occurs due to lack of information of the population, problems of basic sanitation and infrastructure (BRASIL, 2019b). Thus, addressing the barriers already known, Decree №. 8.662 of February 1, 2016, was put into effect (BRASIL, 2016a). It intended to adopt routine measures to limit vector spread through educational campaigns, surveys to eliminate mosquito onset and to clean public facilities. Besides that, the Articulation and Monitoring Committee (Comitê de Articulação e Monitoramento) was established to oversee the actions implemented (DONALISIO MR, et al., 2017).

Due to the difficulty of controlling the vector, and seeking to reinforce the measures previously adopted, the law 13.301 of June 2016 was established (BRASIL, 2016b), requiring the adoption of health surveillance measures in situations of imminent danger by the presence of Aedes aegypti.

Among these measures, there are visits to public and private properties and abandoned residences for surveys and eliminations of possible mosquito breeding places. For surveillance effectiveness, the agent designated for disease control would have the power to enter property to inspect, even when denied permissions by the owner, or in the absence of the dwellers of the residences (BRASIL, 2017; MIRANDA VMC, 2017; BRASIL, 2016b). These measures are essential in the control and elimination of Aedes aegypti breeding sites and enables the population to make anonymous reports of irregular establishments or houses.

Following the measures taken in 2016, the number of probable cases of Zika fever in PE decreased by 90\% from 391 in 2016 to 39 in 2017 (BRASIL, 2017b; BRASIL, 2018a). Then, in 2018, the number of probable cases of Zika fever in PE (113 cases) demonstrated a significant increase of $289 \%$ when compared to 2017 (39 cases) (BRASIL, 2019c).

By August 2019, the number of probable cases of Zika fever in PE (437 cases) increased $386.72 \%$ when compared to the same period of 2018 (113 cases) (BRASIL, 2018b; BRASIL, 2019b). Regarding CZS, in 2017 18 cases were confirmed in PE, an $88.67 \%$ reduction in the number of cases when compared to 2016 (159 confirmed cases) (PERNAMBUCO SESV, 2018). In contrast, the number of confirmed cases of CZS in 2018 fell by $61.11 \%$, from 18 in 2017 to 7 in 2018) (PERNAMBUCO, 2018).

We could not analyze the effectiveness of the control measures adopted during the year of 2016 due to the lack of data of 2015, since notification of the disease only became mandatory in 2016 (MIRANDA VMC, 2017; JESUS UH De, et al., 2018). Public health measures adopted across the years is summarized in Table 1. 
Table 1. Summary of the main actions implemented to combat ZIKV post-outbreak in 2015.

\begin{tabular}{ccccc}
\hline $\begin{array}{c}\text { Year of } \\
\text { implementation }\end{array}$ & Measures Adopted & Goal(s) & $\begin{array}{c}\text { Expected } \\
\text { Outcome }\end{array}$ & Reference \\
\hline 2015 & $\begin{array}{c}\text { National Plan to Combat } \\
\text { Microcephaly }\end{array}$ & $\begin{array}{c}\text { Provide support to } \\
\text { pregnant women and } \\
\text { babies with } \\
\text { microcephaly and } \\
\text { intensify the fight against } \\
\text { the vector } \\
\text { microcephaly } \\
\text { case numbers } \\
\text { and reduction } \\
\text { of vector } \\
\text { infestation }\end{array}$ & (BRASIL, 2015b) \\
\hline Decree № 8.612 & $\begin{array}{c}\text { Monitoring and } \\
\text { management of } \\
\text { measures directed to } \\
\text { vector control }\end{array}$ & $\begin{array}{c}\text { Better control } \\
\text { over vector } \\
\text { infestation }\end{array}$ & (BRASIL, 2015a) \\
\hline 2016 & Decree № 8.662 & $\begin{array}{c}\text { Implement routine } \\
\text { measures to combat } \\
\text { vector }\end{array}$ & $\begin{array}{c}\text { Reduction of } \\
\text { vector } \\
\text { infestation }\end{array}$ & (BRASIL, 2016a) \\
\hline Law 13.301 & $\begin{array}{c}\text { Inspection and } \\
\text { elimination of the vector }\end{array}$ & $\begin{array}{c}\text { Reduction of } \\
\text { vector } \\
\text { infestation }\end{array}$ & (BRASIL, 2016b) \\
\hline
\end{tabular}

Source: Silva HVC, et al., 2020.

According to the illustration shown in Figure 2, it has a strong correlation between growth and development changes in both newborns and children due to infection caused by ZIKV in a national comparison with the state of PE, according to the notifications presented.

Figure 2 shows the number of probable cases of Zika fever and the number of reported cases of newborns and children with growth and developmental changes possibly related to ZIKV infection in Brazil (A) and PE (B).

Despite the increase in the number of ZIKV probable cases this year, the number of cases of microcephaly and neurological disorders have decreased. Between January and August 2019, 63 suspected cases of CZS were reported. In the same period of the previous year the number was 141 cases a reduction of $55.3 \%$ (PERNAMBUCO, 2019b). This reduction can be seen also proportionally, when the year by year PE/BR ratio is analyzed: the ratio was increasing from 2016 to $2018(0.0209,0.0833$ and 0.1021 , respectively) and then decreased to 0.0658 . 
Figure 2 - Comparison between probable cases of Zika fever and reported cases of ZIKV-related growth and developmental changes in Brazil and PE.

A

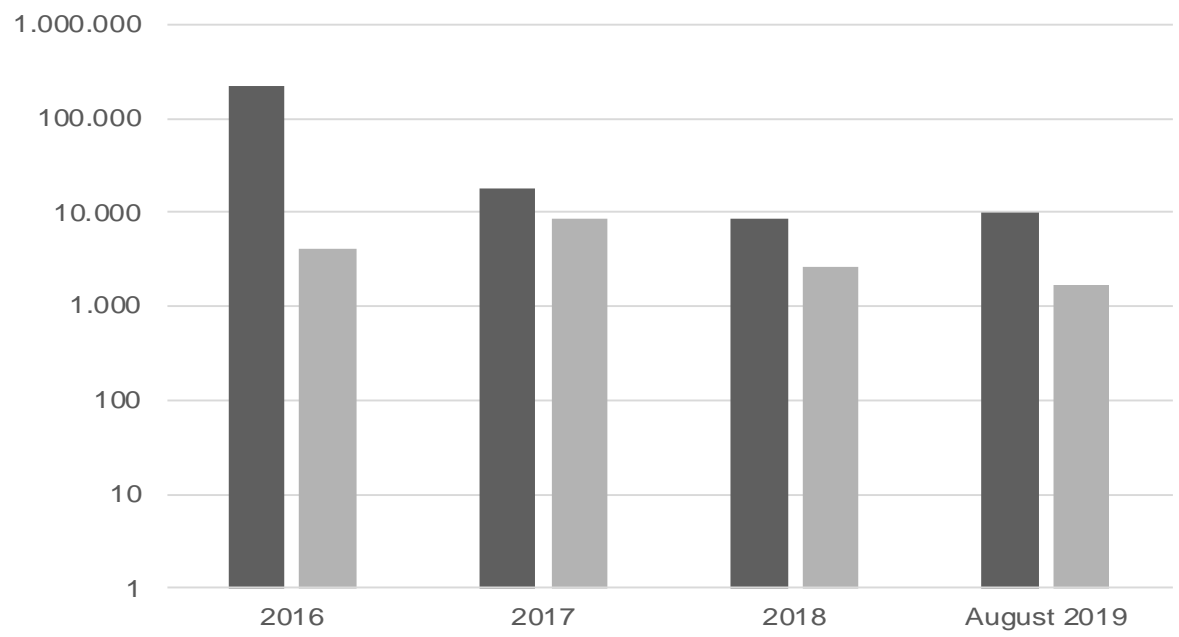

B

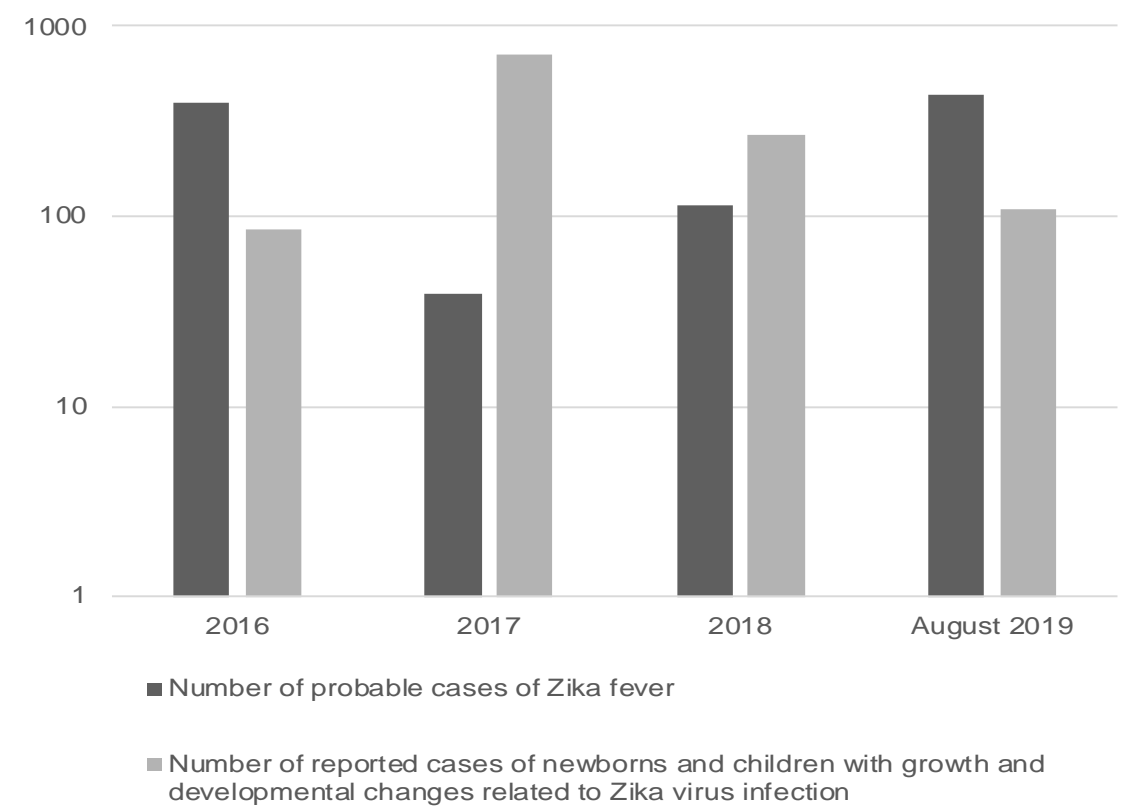

Source: Silva HVC, et al., 2020.

\section{Social-structural aspects}

In a study carried out in Recife (PE), SOUZA et al. (2018) attributes the high number of ZIKV cases to the poor quality of the housing infrastructure, which, for the most part, does not have basic sewage treatment. This, together with the high temperatures and the humid climate, form the optimum environment for the vector and, consequently, favors the emergence of arboviruses. In agreement, SILVA et al. (2016) attributes nonsuccess in the application of vector control policies by the government to social inequality.

Structural policies, therefore, could avoid problems like open sewers and the accumulation of waste and garbage, thus helping to make public health policies more effective. In addition, once many residents perform the practice of improperly storing water in their homes due to water supply insecurity, improvement and implementation in water distribution could also be an efficient strategy. 
Interestingly, a recent study raised a concern in this matter by finding synergism between microcephaly and a neurotoxin (saxitoxin) produced by the freshwater cyanobacteria Raphidiopsis raciborskii, typically found in water reservoirs, especially in the Northeast region, which generally faces periods of severe drought, with the most severe occurring between 2012 and 2016 (PEDROSA C Da SG, et al., 2019).

Answering questions like these is extremely important for maintaining and promoting public health and cannot be achieved without scientific research.

Regarding the scientific research area, emphasis is placed on the need for coordination and integration of groups of studies in the search for rapid answers on the aspects of the disease in the country. Of utmost importance is the dissemination of study protocols for the purpose of comparing results, simplifying the exchange of biological materials and adequate support for science and technology departments for effective contribution to combating ZIKV.

Control-vector policies obviously aid in the control of Aedes aegypti but seem to be only partially effective, once the mosquito is still widely spread even with all aforementioned measures implemented by the government (SOUZA, et al., 2018; SILVA ALN, et al., 2016). Therefore, investments in sanitation, water distribution and research should be prioritized in the control of this problem.

\section{FINAL CONSIDERATIONS}

The Brazilian legislation formulated and implemented control measures from 2015 to 2018 mostly focused on the control of Aedes aegypti. However, the recent increase in the number of reported cases of ZIKV, Dengue and Chikungunya in Brazil proves these measures to be only partially effective. The decrease in the investments in scientific research due to the recent economic crisis makes this scenario even more worrisome.

Clearly, structural problems that lead to the spread of the mosquito must receive special attention from the government. As long as the factors that favor the development and maintenance of mosquito breeding sites, such as lack of basic sanitation, are not eliminated, Brazil will continue to present a potential risk for the dissemination of arboviruses.

\section{FUNDING SOURCE}

This study was financed by the National Council for the Improvement of Higher Education - Brazil (CAPES) - Finance Code 001.

\section{ACKOWLEGDEMENTS}

National Council for the Improvement of Higher Education - Brazil (CAPES), National Council for Scientific and Technological Development - Brazil (CNPq) and the Department of Science and Technology of the Ministry of Health - Brazil (Decit/SCTIE/MS).

\section{REFERENCES}

1. ARAÚJO HRC, et al. Aedes aegypti control strategies in Brazil: Incorporation of new technologies to overcome the persistence of dengue epidemics. Insects. 2015, 6(2): 576-594.

2. BRASIL. Decreto No 7.616, 2011. Dispõe sobre a declaração de Emergência em Saúde Pública de Importância Nacional ESPIN e institui a Força Nacional do Sistema Único de Saúde - FN-SUS. 2011

3. BRASIL. Decreto No 8.612, 2015. Institui a Sala Nacional de Coordenação e Controle, para o enfretamento da Dengue,do Vírus Chinkungunyae do ZikaVírus. 2015a.

4. BRASIL. Decreto de No 8.662, 2016. Dispõe sobre a adoção de medidas rotineiras de prevenção e eliminação de focos do mosquito Aedes aegypti, no âmbito dos órgãos e entidades do Poder Executivo federal, e cria o Comitê de Articulação e Monitoramento das ações de mobilização para a prevenção e eliminação de focos do mosquito Aedes aegypti. 2016a.

5. BRASIL. Lei 13.301, 2016. Dispõe sobre a adoção de medidas de vigilância em saúde quando verificada situação de iminente perigo à saúde pública pela presença do mosquito transmissor do vírus da dengue, do vírus chikungunya e do vírus da zika; e altera a Lei no 6.437, de 20 de agosto de 1977. 2016b.

6. BRASIL. Vírus Zika no Brasil: a resposta do SUS. 1a. Brasília: Secretaria de vigilância em saúde; 2017. 
7. BRASIL. Ministério da Saúde do Brasil (Brazil Ministry of Health). Levantamento rápido de índices para Aedes Aegypti LIRAa - para vigilância entomológica do Aedes Aegypti no Brasil. 2013.

8. BRASIL. Ministério da Saúde do Brasil (Brazil Ministry of Health). Plano Nacional de Enfrentamento à Microcefalia. $2015 \mathrm{~b}$.

9. BRASIL. Ministério da Saúde do Brasil (Brazil Ministry of Health). Boletim Epidemiológico: Monitoramento dos casos de dengue, febre de chikungunya e doença aguda pelo vírus Zika até a Semana Epidemiológica 52, 2015. vol. 47. 2016c.

10. BRASIL. Ministério da Saúde do Brasil (Brazil Ministry of Health). Boletim Epidemiológico: Monitoramento dos casos de microcefalia até a semana epidemiológica 51, 2015. vol. 47. 2016d.

11. BRASIL. Ministério da Saúde do Brasil (Brazil Ministry of Health). Boletim Epidemiológico: Monitoramento dos casos de dengue, febre de chikungunya e febre pelo vírus Zika até a Semana Epidemiológica 52, 2016b. vol. 48. 2017b.

12. BRASIL. Ministério da Saúde do Brasil (Brazil Ministry of Health). Boletim Epidemiológico: Monitoramento dos casos de dengue, febre de chikungunya e febre pelo vírus Zika até a Semana Epidemiológica 52, 2017. vol. 49. 2018a.

13. BRASIL. BRASIL. Ministério da Saúde do Brasil (Brazil Ministry of Health). Boletim Epidemiológico: Monitoramento dos casos de dengue, febre de chikungunya e doença aguda pelo vírus Zika até a Semana Epidemiológica 34, 2018. vol. 49. 2018b.

14. BRASIL. Ministério da Saúde do Brasil (Brazil Ministry of Health). Boletim Epidemiológico: Monitoramento integrado de alterações no crescimento e desenvolvimento relacionadas à infecção pelo vírus Zika e outras etiologias infecciosas, até a Semana Epidemiológica 52, 2018. vol. 50. 2019a.

15. BRASIL. Ministério da Saúde do Brasil (Brazil Ministry of Health). Boletim Epidemiológico: Monitoramento dos casos de arboviroses urbanas transmitidas pelo Aedes (dengue, chikungunya e Zika) das Semanas Epidemiológicas 1 a 34, 2019. vol. 50. 2019b.

16. BRASIL. Ministério da Saúde do Brasil (Brazil Ministry of Health). Boletim epidemiológico: Monitoramento dos casos de dengue, febre de chikungunya e doença aguda pelo vírus Zika até a Semana Epidemiológica 52, 2018. vol. 50. 2019c.

17. BRASIL. Ministério da Saúde do Brasil (Brazil Ministry of Health). Boletim Epidemiológico: Monitoramento dos casos de arboviroses urbanas transmitidas pelo Aedes (dengue, chikungunya e Zika) até a Semana Epidemiológica 12 de 2019 e Levantamento Rápido de Índices para Aedes aegypti (LIRAa). vol. 50. 2019d.

18. CHANG C, et al. The Zika outbreak of the 21 st century. J Autoimmun, 2016 (68): 1-13.

19. DONALISIO MR, et al. Arboviruses emerging in Brazil: challenges for clinic and implications for public health. Rev. saude pública 51, 2017: 30

20. FARIA DOS SANTOS V, VIEIRA CV. Crescimento econômico e desigualdade de renda: uma análise sobre pobreza e extrema pobreza na Região Nordeste do Brasil. Indic. Econ. FEE. 2016;44(2):125-38.

21. HUANG YJS, et al. Emergence and re-emergence of mosquito-borne arboviruses. Curr Opin Virol. 2019; 34:104-9.

22. JESUS UH, et al. Microcefalia Acometida Por Infecção Congênita Pelo Zika Vírus. Rev Da Fac Educ e Meio Ambient FAEMA. 2018; 9:577-83.

23. KINDHAUSER MK, et al. Zika: the origin and spread of a mosquito-borne virus. Bull World Health Organ. 2016;94(9):67586.

24. MARCONDES CB, XIMENES MFFM. Zika virus in Brazil and the danger of infestation by aedes (Stegomyia) mosquitoes. Rev. Soc. Bras. Med. Trop. 2016, 49(1): 4-10.

25. MIRANDA VMC. A eficácia das políticas públicas após a tríplice epidemia Dengue, Zika e Chikungunya. II Congr Int da Divers No Semiárido. 2017:1-6.

26. NEWCOMBE RG. Two-sided confidence intervals for the single proportion: comparison of seven methods. Stat Med. 1998;17(8):857-72.

27. NETA TJC, et al. Ações desenvolvidas no Instituto de Medicina Integral Prof. Fernando Figueira para enfrentamento à microcefalia pelo Zika vírus. Rev Bras Saúde Matern Infant, Recife. 2016;16(1):117-22.

28. NUNES J, PIMENTA D. A epidemia de Zika e os limites da saúde global. Lua Nova: revista de cultura e política, 2016: 21 46.

29. PEDROSA C DA SG, et al. The cyanobacterial saxitoxin exacerbates neural cell death and brain malformations induced by Zika virus. BioRxiv. 2019:755066.

30. PERNAMBUCO. Secretaria Executiva de Vigilância em Saúde do Governo do Estado de Pernambuco - SEVS. Informe Técnico No 06/2018: Síndrome congênita relacionada à infecção pelo vírus Zika. 2018.

31. PERNAMBUCO. Secretaria Executiva de Vigilância em Saúde do Governo do Estado de Pernambuco - SEVS. Bol Arbov SE 52. 2019a.

32. PERNAMBUCO. Secretaria Executiva de Vigilância em Saúde do Governo do Estado de Pernambuco. Informe Técnico No 08/2019: Síndrome congênita relacionada à infecção pelo vírus Zika. $2019 \mathrm{~b}$.

33. QUEIROZ JTM, et al. New premises for sanitation in arbovirus infections control in Brazil. Cad. saúde pública, $2020: 36$.

34. SCHULER-FACCINI L, et al. Possível associação entre a infecção pelo vírus zika e a microcefalia — Brasil, 2015. Cent Dis Control Prev - Morb Mortal Wkly Rep. 2016;65(3):1-4.

35. SILVA LIMA NETO A, et al. Dengue, zika e chikungunya - desafios do controle vetorial frente à ocorrência das três arboviroses - Parte I. Rev Bras Em Promoção Da Saúde. 2016;29(3):305-12.

36. SOLOMON T, et al. Zika virus and neurological disease-approaches to the unknown. Lancet Infect Dis. 2016; 16(4): 402404.

37. SOUZA WV, et al. Microcephaly epidemic related to the Zika virus and living conditions in Recife, Northeast Brazil. BMC Public Health. 2018;18(1):1-7.

38. TEIXEIRA MG, et al. The epidemic of Zika virus-related microcephaly in Brazil: Detection, control, etiology, and future scenarios. Am J Public Health. 2016;106(4):601-5.

39. WILSON EB. Probable Inference, the Law of Succession, and Statistical Inference. J Am Stat Assoc. 1927; $22(158): 209-12$.

40. ZANLUCA C, et al. First report of autochthonous transmission of Zika virus in Brazil. Mem. Inst. Oswaldo Cruz. 2015, 110(4): 569-572. 